\title{
Foliar Nutrition, Biostimulants and Prime-Like Dynamics in Fruit Tree Physiology: New Insights on an Old Topic
}

\author{
Georgia Tanou, Vasileios Ziogas and Athanassios Molassiotis * \\ Laboratory of Pomology, Faculty of Agriculture, Aristotle University of Thessaloniki, Thessaloniki, Greece
}

Despite the fact that the usage of foliar nutrients has long history, many aspects of fertilization through leaves are still unknown. Herein, we review the current knowledge regarding the canopy fertilization putting special emphasis on Fe nutrition and briefly provide insights into the nanofertilizer technology of the foliar feeding of fruit crops. In addition, this paper discusses the main aspects of the foliar application of biostimulants regarding crucial factors of fruit cropping systems, such as fruit yield/size, tolerance to environmental stresses, and nutrient availability. Also, we specifically discuss the role of hydrogen peroxide $\left(\mathrm{H}_{2} \mathrm{O}_{2}\right)$ and nitric oxide (NO) as priming molecules and their possible cross-talk with biostimulants in fruit tree physiology. Finally, a view of the key issues for future fundamental and applied research in the topic is put forward.

OPEN ACCESS

Edited by:

Jose M. Garcia-Mina,

University of Navarra, Spain

Reviewed by:

Ümit Barıș Kutman,

Konya Food and Agriculture

University, Turkey

Federico Scossa,

CREA-Research Center for Fruit

Science, Italy

*Correspondence:

Athanassios Molassiotis amolasio@agro.auth.gr

Specialty section:

This article was submitted to

Plant Nutrition,

a section of the journal

Frontiers in Plant Science

Received: 03 October 2016 Accepted: 12 January 2017

Published: 01 February 2017

Citation:

Tanou G, Ziogas V and Molassiotis A (2017) Foliar Nutrition, Biostimulants and Prime-Like Dynamics in Fruit Tree

Physiology: New Insights on an Old

Topic. Front. Plant Sci. 8:75.

doi: 10.3389/fpls.2017.00075
Keywords: abiotic stress, fruit tree nutrition, priming, reactive nitrogen species, reactive oxygen species, reactive sulfur species

\section{INTRODUCTION}

Fruit tree crops are agricultural commodities of great biological and economical importance, and therefore, precise knowledge of treatments that boost fruit production, is of great importance. It is generally accepted that the appropriate nutrient management is crucial for optimizing fruit crop production. However, fruit growers usually apply larger amounts of chemical fertilizers to the soil than the tree actually needs, resulting to surface runoff and environmental pollution (Vance, 2001). Foliar sprays have been also used as an important tool to meet tree nutrient demand. This fertilization method is more target-oriented and environmental friendly since the nutrients are applied in controlled quantities (Fernández and Eichert, 2009).

Perennial fruit trees are frequently exposed to various abiotic stresses during their lifetime that limit crop yield. To face this problem, modern fruit tree physiology is currently focused, among others, on the stimulation of stress-related tolerance mechanisms and plant cell development programs using biostimulants. Biostimulants are incorporated in the practice of fruit production due to their ability to enhance nutrient uptake, stimulate plant development and minimize the use of fertilizers (Kunicki et al., 2010). Despite the widespread use of biostimulators in fruit industry, their precise mechanisms of action remain unknown. On the other hand, the use of priming techniques (e.g., external application of natural or synthetic compounds in plants to induce acclimation against environmental stresses) has also received much attention in recent years (Tanou et al., 2012b). The priming (also called hardening) is a process by which plants attain a unique physiological state called "primed" state, after a pre-treatment with a given priming agent. Detailed study of the molecular aspects of priming in plants, including fruit crops has recently been reviewed elsewhere (Conrath, 2011; Tanou et al., 2012b; Molassiotis et al., 2016). 
This review is divided into three parts. The first provides a short overview of foliar fertilization in fruit tree physiology. The second part covers the biostimulants effects and possible physiological mechanisms, while the last part refers to tree responses to hydrogen peroxide $\left(\mathrm{H}_{2} \mathrm{O}_{2}\right)$ and nitric oxide (NO) priming agents. Finally, the interplay between biostimulants and $\mathrm{H}_{2} \mathrm{O}_{2}-$ and $\mathrm{NO}$-associated priming in whole-tree physiology is also addressed.

\section{CANOPY FERTILIZATION IN FRUIT TREES IN GENERAL: Fe DEFICIENCY AS AN EXAMPLE}

Taking into account the limitations of nutrients addition through soil, foliar sprays are an effective way to meet the plants nutrients requirements (Wójcik, 2004). The most common macronutrients applied as foliar fertilizers are $\mathrm{N}$ (as urea, ammonium nitrate and ammonium sulfate), $\mathrm{P}$ [as $\mathrm{H}_{3} \mathrm{PO}_{4}, \mathrm{KH}_{2} \mathrm{PO}_{4}, \mathrm{NH}_{4} \mathrm{H}_{2} \mathrm{PO}_{4}$, $\mathrm{Ca}\left(\mathrm{H}_{2} \mathrm{PO}_{4}\right)_{2}$ and phosphites], $\mathrm{K}$ (as $\mathrm{K}_{2} \mathrm{SO}_{4}, \mathrm{KCl}, \mathrm{KNO}_{3}, \mathrm{~K}_{2} \mathrm{CO}_{3}$, $\mathrm{KH}_{2} \mathrm{PO}_{4}$ ), $\mathrm{Mg}$ (as $\left.\mathrm{MgSO}_{4}, \mathrm{MgCl}_{2}, \mathrm{Mg}\left(\mathrm{NO}_{3}\right)\right]_{2}$, and $\mathrm{Ca}\left(\right.$ as $\mathrm{CaCl}_{2}$, Ca-propionate, $\mathrm{Ca}$-acetate). Also, to the most commonly foliarapplied micronutrients belong the $\mathrm{B}$ [as boric acid $\left(\mathrm{B}(\mathrm{OH})_{3}\right.$ ], borax $\left(\mathrm{Na}_{2} \mathrm{~B}_{4} \mathrm{O}_{7}\right)$, Na-octoborate $\left(\mathrm{Na}_{2} \mathrm{~B}_{8} \mathrm{O}_{13}\right)$, B-polyols, Fe [as $\mathrm{FeSO}_{4}, \mathrm{Fe}(\mathrm{III})$-chelates, Fe-complexes], $\mathrm{Mn}$ [as $\mathrm{MnSO}_{4}, \mathrm{Mn}(\mathrm{II})$ chelates], and $\mathrm{Zn}$ [as $\mathrm{ZnSO}_{4}, \mathrm{Zn}$ (II)-chelates, $\mathrm{ZnO}$, Zn-organic 'complexes] (Fernández et al., 2013). Historically, research on foliar fertilization was started at the late 1940s and early1950s. Later, extensive foliar fertilization research was conducted for high-value fruit crops challenged with microelement deficiencies. Recently, a considerable amount of new information has been gathered regarding the absorption, translocation, and utilization of foliar-applied nutrients by fruit trees (Fernández and Brown, 2013). Given that the penetration of the cuticle is generally considered to be the rate-limiting step for foliar nutrition, several hypotheses about the penetration of nutrient via the cuticle have been raised (Fernández et al., 2016). For instance, there is evidence, although still not extensive, that polar paths of diffusion across cuticles exist (Niemann et al., 2013). Ionic compounds use aqueous polar paths of diffusion, whereas lipophilic molecules diffuse along the lipophilic wax and cutin domains (Schreiber, 2005). The nature of these polar domains remains to be explained in more detail.

In many orchards, macronutrients and especially micronutrients, such as $\mathrm{B}, \mathrm{Zn}, \mathrm{Mn}$, and $\mathrm{Fe}$ were leafapplied regularly to prevent the deficiencies of these elements. Particularly, Fe chlorosis is recognized as a suitable model to study foliar fertilization since it represents a common nutritional problem in several fruit crops, such as citrus, pear, and peach trees, grown on calcareous soils (Molassiotis et al., 2006). Correction of $\mathrm{Fe}$ chlorosis is generally carried out by soil application of synthetic Fe(III) chelates, which are usually quite effective. Iron foliar fertilization is a cheaper and more environmentally-friendly alternative to soil treatments with synthetic Fe(III) chelates for the control of Fe chlorosis in trees (El-Jendoubi et al., 2011). Hence, a great deal of additional work is required to understand leaf Fe uptake as well as the characteristics of $\mathrm{Fe}$ fertilizers. Using X-ray emission, ElJendoubi et al. (2014) showed that foliar Fe-sulfate fertilization in Fe-deficient peach leaves were minor outside the leaf surface, indicating that Fe mobility within the leaf is a major constraint for fertilizer effectiveness in fruit crops. Recently, Rios et al. (2016) showed that Fe applied as inorganic salts was absorbed rapidly through the stomata of Prunus rootstock GF 677; strong labile Fe pools stained with blue Perls were detected in vascular areas of the leaf blade and the central vein in response to FeSO, whereas in the case of $\mathrm{Fe}$ (III) salts the stain remained at the stomatal area. These results give the possibility to test new Fe fertilizer formulations easily, as well as to study the possible $\mathrm{Fe}$ transporters responsible for leaf Fe uptake.

It is noteworthy that, in parallel to the studies on the role of essential nutrients, the function of the beneficial elements on fruit physiology was recently investigated. For instance, the potential effect of leaf-applied titanium (Ti) and silicon ( $\mathrm{Si}$ ) in apple and sapota tree vigor and yield has been proposed (Wójcik et al., 2010; Thippeshappa et al., 2014). In addition to this, it has become apparent that foliar nutrients can regulate flowering, fruit yield and fruit quality. For example, several studies revealed that foliar sprays of B increase pollen-tube germination and fruit set in a number of tree species (Wang et al., 2015).

\section{NANOTECHNOLOGY CAN BOOST FOLIAR NUTRITION PRACTICES}

Nanotechnology is a multidisciplinary and rapidly growing field in science and technology, which involves the manufacture, processing and application of nanometer scale assemblies of atoms and molecules. Nanomaterials are classified as materials with at least one dimension less than $100 \mathrm{~nm}$ (Sekhon, 2014). The most important application of nanotechnology in agricultural crop production is the field of nano-fertilizers. Nanofertilizers are nutrient carriers of nano-dimensions capable of binding nutrient ions due to their high surface area and release it slowly and steadily that commensurate with crop demand (Subramanian et al., 2015). In nanofertilizers, nutrients can be encapsulated by nanomaterials, coated with a thin protective film, or delivered as emulsions or nanoparticles. The smaller size, the higher specific surface area and the reactivity of nanofertilizers may affect nutrient solubility, diffusion and hence availability to plants (Singh et al., 2013). Nanofertilizer technology is very innovative, and scant reported literature is available concerning fruit trees. In this context, Davarpanah et al. (2016) indicated that the foliar application of nano- $\mathrm{Zn}$ and nano-B fertilizers in pomegranate increased the leaf concentrations of both microelements, reflecting the improvements in tree nutrient status. Thus, more detailed and comprehensive work is needed in this important area of research.

\section{AGRICULTURAL BIOSTIMULANTS IN BRIEF: DEFINITION, CATEGORIES, AND MODE OF ACTION}

Although the term "biostimulant" has been used for many years, it is still not fully defined. According to European 
Biostimulant Industry Council (EBIC) "plant biostimulants contain substance(s) and/or micro-organisms whose function when applied to plants or the rhizosphere is to stimulate natural processes to enhance/benefit nutrient uptake, nutrient efficiency, tolerance to abiotic stress, and crop quality" (http://www.biostimulants.eu). The review of the relevant literature reveals a wide range of compounds, including humic and fulvic acids, protein hydrolysates and other $\mathrm{N}$-containing compounds, seaweed extracts and botanicals, chitosan and other biopolymers, beneficial fungi and bacteria potentially act as a biostimulant (du Jardin, 2015). Several studies documented that biostimulants promote plant growth, development and productivity (Brown and Saa, 2015; Bulgari et al., 2015), however the mechanism of action is poorly or not understood. It is possible that the beneficial effects of biostimulant on growth parameters could be ascribed to auxin and gibberellin-like activity, and enhanced nitrogen uptake, as documented for the biostimulant action of plant-derived protein hydrolysate in corn, tomato, and gibberellin-deficient dwarf pea plants (Colla et al., 2014). Another suggested function of biostimulants was linked to reactive oxygen/nitrogen species and hormonal signaling. For example, chitosan, a natural biopolymer produced from chitin, is the major constituent of arthropods exoskeleton and fungi cell walls and has been extensively studied as an elicitor for inhibiting postharvest senescence and diseases in many fruit, such as apple, citrus, kiwifruit, peach, pear, strawberry, and sweet cherry (Kerch, 2015). It has has been proposed that chitosan binds to the cell membrane generating $\mathrm{H}_{2} \mathrm{O}_{2}$ and $\mathrm{NO}$ in chloroplast; $\mathrm{H}_{2} \mathrm{O}_{2}$ activates the reactive oxygen species (ROS) scavenging system and abscisic acid (ABA) biosynthesis, while NO induces phosphatidic acid (PA) synthesis through phospholipase C (PLC) and diacylglycerol kinase (DGK) (PLC/DGK) pathways. PA enhances ABA signaling by inhibiting ABI1 (the negative regulator of $A B A$ ) whereas $\mathrm{H}_{2} \mathrm{O}_{2}$ stimulates jasminic acid (JA) signaling via octadecanoid pathway resulting in the up-regulation of chitosan-responsive genes (e.g., chitinase or glucanase) (Pichyangkura and Chadchawan, 2015).

\section{BIOSTIMULANTS REGULATE MAJOR FRUIT TREE PHYSIOLOGICAL TRAITS}

Studies with annual plants and model species suggested that biostimulants could enhance growth, development and tolerance to abiotic stress. However, availability of this information is relative limited for fruit crops probably due to the fact that the studies with fruit trees have many disadvantages; such as the long juvenility, the large body size (require large cultivation space), the abiotic and biotic stress conditions experiencing throughout the year. Table 1 gives an overview of the available information concerning the effects of various biostimulants in fruit crops.

\section{Foliar Application of Biostimulants Promote Fruit-Related Growth Characteristic}

Protein hydrolysates receive attention as biostimulants in fruit science. It has been demonstrated that commercial mixtures of protein hydrolysates enhanced the overall yield in papaya (Morales-Payan and Stall, 2003) and apple (Dubravec et al., 1995). Quartieri et al. (2002) studied the effect of foliar application of animal-derived protein hydrolysates obtained by different rates of protein hydrolysis at kiwi plants. These authors reported that the fraction with the lowest molecular weight and at low doses stimulated shoot and root biomass, while the fraction with high molecular weight was able to promote shoot growth. In banana tree, feather-derived protein hydrolysates minimized the harvesting date by 28 days and enhanced the number of hands per brunch, fingers per hand and brunch. Although the exact mechanism remains unknown, this is likely to occur through higher chlorophyll and reduced sugar contents (Morales-Payan and Stall, 2004).

Several commercial and experimental seaweed extracts can also be employed to produce potent biostimulants. Foliar application of A. nodosum extract in kiwi plants after flowering increased the weight and maturity of the harvested fruits (Chouliaras et al., 1997). In clementine and orange trees, foliar spray of seaweed extracts at budding stage positively affected bud sprouting and full bloom, and enhanced gibberellin content and fruit yield (Fornes et al., 2002). Apple trees treated with seaweed extract exerted an improved flowering, vegetative growth and yield (Basak, 2008). Treatment of seaweed extracts to olive plants before bloom improved oil quality characteristics (Chouliaras et al., 2009) as well as mineral content, leaf dry weight and stem diameter (Zulaikha, 2013). Application of seaweed extract to peanut leaves enhanced seed yield and increased the protein content of the harvested seed (Featonby-Smith and van Staden, 1987). In the work of Colavita et al. (2011), foliar application of seaweed extract in pear tree increased fruit diameter, fruit weight and number of cell per area of parenchymatous tissue. Additionally, seaweed extracts have shown promising results as growth-yieldpromoting agents in tropical trees (Mohamed and El-Sehrawy, 2013; Karthikeyan and Shanmugam, 2014). Experiments with citrus plants showed enhanced yield and fruit quality (mineral status/acidity) following foliar application of moringa leaf or pollen grain extract/yeast extracts (El-Boray et al., 2015; Nasir et al., 2016).

\section{Biostimulants Enhanced Tolerance to Environmental Stress and Improved Nutrient Availability}

Another well-known physiological action of biostimulants is their ability to induce tree tolerance against environmental stress. Hamlin' sweet orange trees exposed to commercial extract of brown seaweed displayed tolerance toward drought (Spann and Little, 2011). In another study, citrus plants sprayed with seaweed extract, under drought conditions, showed intermediate water use efficiency (Little and Spann, 2010). The overall results suggested that seaweed extract promotes stem water potential in citrus rootstocks under full irrigation and drought, as well as affects photosynthesis, stomatal conductance and water use efficiency in a cultivar-dependent manner (Little and Spann, 2010). 
TABLE 1 | Functions of biostimulants in fruit tree species.

\begin{tabular}{|c|c|c|c|c|c|c|}
\hline & Biostimulant & Tree species & Physiological effect & $\begin{array}{l}\text { Mode of } \\
\text { application }\end{array}$ & $\begin{array}{l}\text { Biological origin of } \\
\text { the biostimulant }\end{array}$ & References \\
\hline \multirow[t]{15}{*}{$\begin{array}{l}\text { Fruit related and } \\
\text { growth }\end{array}$} & Protein hydrolysate & Papaya & Increased fruit yield & Foliar spray & $\begin{array}{l}\text { Acethylthioprodione } \\
\text { and hydrolized animal } \\
\text { skin derived } \\
\text { aminoacids }\end{array}$ & $\begin{array}{l}\text { Morales-Payan } \\
\text { and Stall, } 2003\end{array}$ \\
\hline & Protein hydrolysate & Kiwi & Stimulated shoot and root growth & Foliar spray & $\begin{array}{l}\text { Protein hydrolysates } \\
\text { from enzymatic } \\
\text { hydrolysis of "peptone } \\
\text { from gelatine" }\end{array}$ & $\begin{array}{l}\text { Quartieri et al., } \\
2002\end{array}$ \\
\hline & Protein hydrolysate & Passion fruit & Increased seedling growth & Foliar spray & $\begin{array}{l}\text { Animal derived Protein } \\
\text { hydrolysate }\end{array}$ & $\begin{array}{l}\text { Morales-Payan } \\
\text { and Stall, } 2004\end{array}$ \\
\hline & Protein hydrolysate & Apple & $\begin{array}{l}\text { Increased leaf chlorophyll and } \\
\text { carotenoid content, enhanced } \\
\text { photosynthesis, increase fruit } \\
\text { yield/size }\end{array}$ & Foliar spray & $\begin{array}{l}\text { Commercial extract } \\
\text { containing zeatin, } \\
\text { triacontanol and a } \\
\text { commercial extract of } \\
\text { L-cysteine and folic } \\
\text { acid derivative }\end{array}$ & $\begin{array}{l}\text { Dubravec et al., } \\
1995\end{array}$ \\
\hline & Seaweed extract & Kiwifruit & $\begin{array}{l}\text { Increased fruit weight/length and } \\
\text { shorten maturation time }\end{array}$ & Foliar spray & $\begin{array}{l}\text { Ascophyllum nodosum } \\
\text { extract }\end{array}$ & $\begin{array}{l}\text { Chouliaras et al., } \\
1997\end{array}$ \\
\hline & Seaweed extract & Citrus & Increased fruit yield & Foliar spray & $\begin{array}{l}\text { Ascophyllum nodosum } \\
\text { extract }\end{array}$ & Fornes et al., 2002 \\
\hline & Seaweed extract & Olive & $\begin{array}{l}\text { Increased fruit yield/oil content, } \\
\text { increased oil linolenic and oleic acid } \\
\text { and accelerated fruit maturation. } \\
\text { Reduced oil palmitoleic stearic and } \\
\text { linoleic acid }\end{array}$ & Foliar spray & $\begin{array}{l}\text { Ascophyllum nodosum } \\
\text { extract }\end{array}$ & $\begin{array}{l}\text { Chouliaras et al., } \\
2009\end{array}$ \\
\hline & Seaweed extract & Peanut & Increased seed protein content & Foliar spray & $\begin{array}{l}\text { Commercial Ecklonia } \\
\text { maximaseaweed } \\
\text { extract (Kelpak 66) }\end{array}$ & $\begin{array}{l}\text { Featonby-Smith } \\
\text { and van Staden, } \\
1987\end{array}$ \\
\hline & Seaweed extract & Pear & $\begin{array}{l}\text { Increased fruit } \\
\text { yield/diameter/weight and number } \\
\text { of cells per area of parenchymatous } \\
\text { tissue of the fruit }\end{array}$ & Foliar spray & $\begin{array}{l}\text { Ascophyllum nodosum } \\
\text { extract }\end{array}$ & $\begin{array}{l}\text { Colavita et al., } \\
2011\end{array}$ \\
\hline & Seaweed extract & Olive & $\begin{array}{l}\text { Increased plant height, leaf } \\
\text { number/dry weight, leaf Zn content, } \\
\text { stem diameter }\end{array}$ & Foliar spray & $\begin{array}{l}\text { Commercial seaweed } \\
\text { extract (Sea Force) }\end{array}$ & Ibrahim, 2013 \\
\hline & Seaweed extract & Mango & $\begin{array}{l}\text { Increased leaf area and leaf N, P, K, } \\
\mathrm{Mg}, \mathrm{Zn}, \mathrm{Fe} \text {, and Mn content. } \\
\text { Increased fruit } \\
\text { retention/weight,/yield/soluble } \\
\text { sugars. Reducing vitamin C and } \\
\text { acidity }\end{array}$ & Foliar spray & $\begin{array}{l}\text { Ascophyllum nodosum } \\
\text { extract }\end{array}$ & $\begin{array}{l}\text { Mohamed and } \\
\text { El-Sehrawy, } 2013\end{array}$ \\
\hline & Seaweed extract & Banana & $\begin{array}{l}\text { Increased fruit yield, minimized fruit } \\
\text { moisture content and increased fruit } \\
\text { carbohydrate, protein and mineral } \\
\text { content }\end{array}$ & Foliar spray & $\begin{array}{l}\text { Commercially } \\
\text { Kappapphycus alvarezii } \\
\text { extract }\end{array}$ & $\begin{array}{l}\text { Karthikeyan and } \\
\text { Shanmugam, } \\
2014\end{array}$ \\
\hline & Seaweed extract & Apple & $\begin{array}{l}\text { Increased fruit yield/size, increased } \\
\text { growth of shoots and leaves, } \\
\text { prolonged flower blooming time }\end{array}$ & Foliar spray & $\begin{array}{l}\text { Commercially Ecklonia } \\
\text { maxima and } \\
\text { Ascophyllum nodosum } \\
\text { extracts }\end{array}$ & Basak, 2008 \\
\hline & Humic substances & Apricot & $\begin{array}{l}\text { Increased vegetative growth, fruit } \\
\text { yield/size/firmness, and soluble } \\
\text { sugar content/acidity ratio }\end{array}$ & $\begin{array}{l}\text { Foliar spray } \\
\text { and soil } \\
\text { applications }\end{array}$ & $\begin{array}{l}\text { Commercial Leonardite } \\
\text { derived humic acid } \\
\text { (Actasol) }\end{array}$ & Fathy et al., 2010 \\
\hline & Humic substances & Olive & $\begin{array}{l}\text { Increased fruit yield/average size } \\
\text { (volume), weight, shape index } \\
\text { (length\diameter), pulp\pit ratio and } \\
\text { moisture content. Decreased fruit } \\
\text { acidity }\end{array}$ & Foliar spray & $\begin{array}{l}\text { Commercial Leonardite } \\
\text { derived humic acid } \\
\text { (Actasol) }\end{array}$ & $\begin{array}{l}\text { Hagagg et al., } \\
2013\end{array}$ \\
\hline
\end{tabular}


TABLE 1 | Continued

\begin{tabular}{|c|c|c|c|c|c|c|}
\hline & Biostimulant & Tree species & Physiological effect & $\begin{array}{l}\text { Mode of } \\
\text { application }\end{array}$ & $\begin{array}{l}\text { Biological origin of } \\
\text { the biostimulant }\end{array}$ & References \\
\hline & Moringa leaf extract & Citrus & $\begin{array}{l}\text { Increased leaf N, P, K, Ca, Mn and } \\
\text { Zn. Minimized fruit drop/set. } \\
\text { Increased yield, fruit } \\
\text { weight/juice/soluble solid contents, } \\
\text { vitamin C, sugars, total antioxidants } \\
\text { and phenolic contents. Increased } \\
\text { activity of SOD and CAT enzymes in } \\
\text { fruit juice }\end{array}$ & $\begin{array}{l}\text { Foliar spray } \\
\text { and soil } \\
\text { applications }\end{array}$ & $\begin{array}{l}\text { Moringa olifera leaf } \\
\text { extract }\end{array}$ & Nasir et al., 2016 \\
\hline & $\begin{array}{l}\text { Pollen grain } \\
\text { extarcts/yeast } \\
\text { extract }\end{array}$ & Citrus & $\begin{array}{l}\text { Improved fruit set/yield/weight. } \\
\text { Reduced fruit drop and fruit acidity }\end{array}$ & Foliar spray & $\begin{array}{l}\text { Brassica napus pollen } \\
\text { grain extract (Milagrow) } \\
\text { and bread yeast } \\
\text { (Saccharomyces } \\
\text { cervisia) extract }\end{array}$ & $\begin{array}{l}\text { El-Boray et al., } \\
2015\end{array}$ \\
\hline \multirow[t]{7}{*}{$\begin{array}{l}\text { Enviromental } \\
\text { stress and nutrition }\end{array}$} & Protein hydrolysate & Pecan & $\begin{array}{l}\text { Increased nut weight, kernel } \\
\text { weight/length/breadth. Increased } \\
\text { fruit size and weight, increased } \\
\text { kernel protein content and Zn, Fe, } \\
\text { Mn, Cu foliar content }\end{array}$ & Foliar spray & $\begin{array}{l}\text { Commercial organic } \\
\text { biostimulant } \\
\text { (Supramino) combined } \\
\text { with urea, boric acid } \\
\text { and zinc sulfate }\end{array}$ & Ashraf et al., 2013 \\
\hline & Amino acid chelate & Pear & $\begin{array}{l}\text { Increased leaf } \mathrm{Fe}, \mathrm{Cu}, \mathrm{Mn} \text { and } \mathrm{Zn} \\
\text { content }\end{array}$ & Foliar spray & $\begin{array}{l}\text { Commercial aminoacid } \\
\text { chelate foliar fertlizers } \\
\text { (Kemito Inc.) }\end{array}$ & Koksal et al., 1999 \\
\hline & Seaweed extract & Citrus & $\begin{array}{l}\text { Increased shoot length/dry weight, } \\
\text { leaf area/dry weight and stem water } \\
\text { potential. Increase plant water use } \\
\text { efficiency. Decreased leaf } \\
\text { photosynthesis/stomatal }\end{array}$ & $\begin{array}{l}\text { Soil drench or } \\
\text { foliar } \\
\text { application }\end{array}$ & $\begin{array}{l}\text { Commercial } \\
\text { Ascophyllum nodosum } \\
\text { extract (Stimplex) }\end{array}$ & $\begin{array}{l}\text { Little and Spann, } \\
2010\end{array}$ \\
\hline & Seaweed extract & Citrus & $\begin{array}{l}\text { Increased growth and stem water } \\
\text { potential }\end{array}$ & $\begin{array}{l}\text { Soil drench or } \\
\text { foliar } \\
\text { application }\end{array}$ & $\begin{array}{l}\text { Brown Ascophyllum } \\
\text { nodosum seaweed } \\
\text { extract }\end{array}$ & $\begin{array}{l}\text { Spann and Little, } \\
2011\end{array}$ \\
\hline & Seaweed extract & Almond & $\begin{array}{l}\text { Increased shoot leaf area, shoot } \\
\text { length and biomass }\end{array}$ & Foliar spray & $\begin{array}{l}\text { Mixture of commercial } \\
\text { plant based } \\
\text { biostimulants (MegaFol, } \\
\text { Brexil-Zn, and } \\
\text { MC-Extra) and } \\
\text { commercial microbial } \\
\text { fermentation product } \\
\text { derived from a } \\
\text { proprietary mix of } \\
\text { organic cereal grains } \\
\text { (GroZyme) }\end{array}$ & Saa et al., 2015 \\
\hline & Humic substances & Apricot & $\begin{array}{l}\text { Increased tree yield, vegetative } \\
\text { growth, total leaf chlorophyll and } \\
\text { leaf } \mathrm{N}, \mathrm{P}, \mathrm{K}, \mathrm{Mg} \text { content }\end{array}$ & Foliar spray & $\begin{array}{l}\text { Commercial Leonardite } \\
\text { derived humic acid } \\
\text { (Actosol) and yeast } \\
\text { (Saccharomyces } \\
\text { cerevisiae) extract }\end{array}$ & Fatma et al., 2015 \\
\hline & Leonardite extract & Olive & $\begin{array}{l}\text { Increased shoot growth, and leaf } \mathrm{K} \text {, } \\
\mathrm{B}, \mathrm{Mg}, \mathrm{Ca} \text { and Fe content }\end{array}$ & Foliar spray & $\begin{array}{l}\text { Leonardite derived } \\
\text { humic acid }\end{array}$ & $\begin{array}{l}\text { Fernández- } \\
\text { Escobar et al., } \\
1996\end{array}$ \\
\hline \multirow[t]{2}{*}{ Tree physiology } & Protein hydrolysate & Banana & $\begin{array}{l}\text { Provoked early flowering; increased } \\
\text { leaf chlorophyll and proline content. } \\
\text { Reduced fruit sugars, proteins, } \\
\text { amino acids, phenolics and } \\
\text { flavonoids }\end{array}$ & $\begin{array}{l}\text { Foliar spray } \\
\text { and soil } \\
\text { applications }\end{array}$ & $\begin{array}{l}\text { Chicken feather derived } \\
\text { Protein hydrolysate }\end{array}$ & $\begin{array}{l}\text { Gurav and Jadhav, } \\
2013\end{array}$ \\
\hline & Protein hydrolysate & Olive & Increased pollen tube elongation & Foliar spray & $\begin{array}{l}\text { Animal derived Protein } \\
\text { hydrolysate (Siapton) }\end{array}$ & Viti et al., 1990 \\
\hline
\end{tabular}

Enhanced fruit tree growth and yield by biostimulants have been accompanied in some cases by improved nutrient uptake. For example, pear (cv. Williams) leaves treated with amino acid chelate showed higher leaf $\mathrm{Fe}$ and $\mathrm{Zn}$ content (Koksal et al., 1999). Pecan trees treated with protein hydrolysates extract increased $\mathrm{Zn}, \mathrm{Fe}, \mathrm{Mn}$, and $\mathrm{Cu}$ foliar content (Ashraf 
et al., 2013). Leave-applied humic substances in apricot and olive trees stimulated mineral level ( $\mathrm{N}, \mathrm{P}, \mathrm{K}$, and $\mathrm{Mg}$ ) (Fatma et al., 2015) while seaweed extracts improved shoot growth and leaf area upon nutrient deprivation in almond tree (Saa et al., 2015). In addition, leonardite extract enhanced $\mathrm{K}, \mathrm{B}, \mathrm{Mg}, \mathrm{Ca}$, and $\mathrm{Fe}$ accumulation in olive leaves (Fernández-Escobar et al., 1996), indicating that humic substances may affect nutrient leaf content through mechanisms other than the direct formation of complexes and chelates in the soil. The plant hormone like activity attributable to humic substances (Mora et al., 2014) is probably the main biological factor responsible for the positive effects exerted by humic substances on fruit tree physiology.

\section{Biostimulants Influenced Specific Features of Fruit Tree Physiology}

In addition to the above well-established role of biostimulants, some interesting data revealed that biostimulants are able to regulate specific physiological features in fruit trees. For example, their application has been correlated with increased biosynthesis of antioxidant-related compounds. Chicken feather-derived protein hydrolysate applied in banana plants at flower induction period enhanced the accumulation of several bioactive substances, like amino acids, phenolics, and flavonoids (Gurav and Jadhav, 2013). Finally, Viti et al. (1990) demonstrated the positive effect of foliar application of a commercial protein hydrolysate upon in vivo and in vitro pollen tube elongation in olive plants.

\section{$\mathrm{H}_{2} \mathrm{O}_{2}$ AND NO PRIMING DYNAMIC IN FRUIT TREE PHYSIOLOGY}

Reactive oxygen (e.g., $\mathrm{H}_{2} \mathrm{O}_{2}$ ), nitrogen (e.g., $\mathrm{NO}$ ), and sulfur (e.g., $\mathrm{H}_{2} \mathrm{~S}$ ) molecules are currently recognized as important signaling species involved in stress acclimation. So far, only few studies provide convincing data for the induction of a primed state of fruit trees in the context of environmental stress. Experimental evidence on $\mathrm{H}_{2} \mathrm{O}_{2}, \mathrm{NO}$, or $\mathrm{H}_{2} \mathrm{~S}$ root-treated Citrus aurantium plants demonstrated that these chemical treatments enhance acclimation to salinity and drought (Molassiotis et al., 2016). As a general conclusion, $\mathrm{H}_{2} \mathrm{O}_{2}$ and $\mathrm{NO}$ chemical treatments altered many proteins involved in photosynthesis process (e.g., Rubisco activase, phosphoglyceratekinase, glyceraldehyde-3-phosphate dehydrogenase, phosphoribulokinase, carbonicanhydrase) and regulated ROS/RNS-based posttranslational protein modifications (PTMs), such as protein carbonylation, $S$-nitrosylation, tyrosine (Tyr) nitration, thereby altering leaf protein function and activity (Tanou et al., 2009, 2012a). In another report, it was demonstrated recently that NaHS initially triggers a signaling stream in leaves where the level of nitrite, NOx, $S$-nitrosoglutahione reductase, and the expression of genes involved in NO-generation (eg., NR, NiR, NOS-like, NADHox, NADHde, AOX) along with the expression of genes involved in ABA biosynthesis (eg., 9-cis-epoxycarotenoiddioxygenase), play a pivotal role in citrus acclimation to drought stress (Ziogas et al., 2015; Figure 1).

Apart from $\mathrm{H}_{2} \mathrm{O}_{2}$ and $\mathrm{NO}$, there are experimental data, although not extensive, indicating that melatonin (Mel) plays signaling roles in several physiological process of trees species.

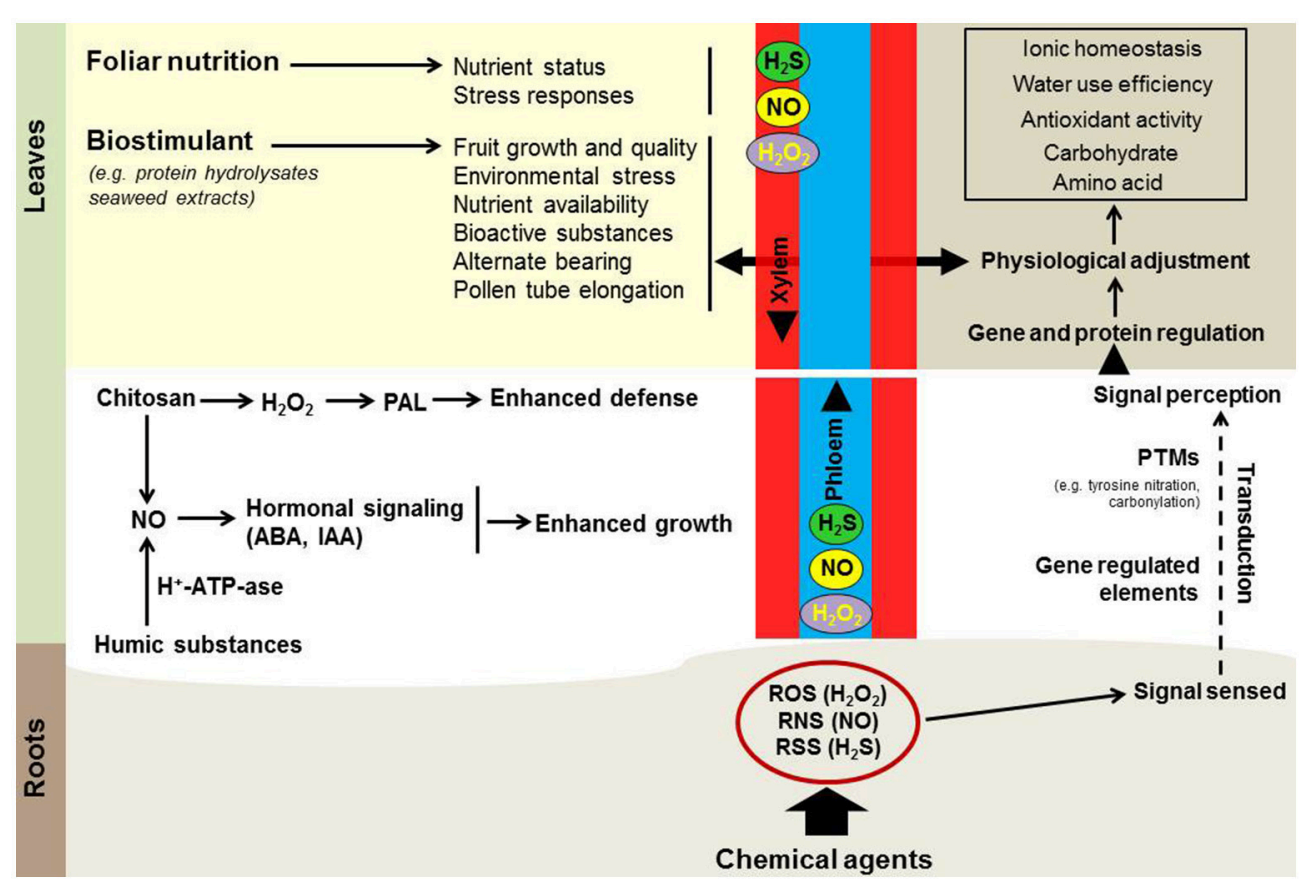

FIGURE 1 | Model of likely biostimulant interaction with $\mathrm{H}_{2} \mathrm{O}_{2}$, NO, and $\mathrm{H}_{2} \mathrm{~S}$ priming signaling in fruit trees (see text for details). 
For instance, root-applied $\mathrm{Mel}$ prevented $\mathrm{NaCl}$-associated toxicity symptoms in leaves of $C$. aurantium seedlings and regulated the expression of an osmoregulated gene (MIPS), an anion-associated channel (SLAH1), and a salt-response transcription factor (MYB73), indicating that sugar metabolism, ion homeostasis and transcription regulation were triggered by Mel (Kostopoulou et al., 2015). Also, Mel treatment activates $\mathrm{H}_{2} \mathrm{O}_{2}$-scavenging enzymes, which might be a part of the mechanism implicated in the delay of senescence in peach fruit (Gao et al., 2016). However, a limited number of data have been obtained with Mel application in leaves of fruit trees. In a particular interesting paper, exogenous Mel delayed darkinduced senescence in apple leaves through the enhancement of some ROS scavenging enzyme activities, which contributed to the elimination of the $\mathrm{H}_{2} \mathrm{O}_{2}$ excess generated in stressed leaves, while maintained the ascorbic acid and glutathione content higher than in control leaves (Wang et al., 2012). Future work is required to identify novel roles for Mel and their interaction with other ROS signals in fruit tree physiology.

\section{INTERPLAY OF BIOSTIMULANTS WITH $\mathrm{H}_{2} \mathrm{O}_{2}$ AND NO PRIMING}

A body of evidence supports the existence of a link between biostimulants and $\mathrm{H}_{2} \mathrm{O}_{2}$ /NO-based priming in several metabolic processes. An example is that chitosan application in plant tissues triggers an $\mathrm{H}_{2} \mathrm{O}_{2}$-originated oxidative burst (Zhao et al., 2007) that orchestrates the induction of plant defense enzymes, including phenylalanine ammonia-lyase (PAL), a key enzyme in phenolics biosynthesis. Increased PAL activity and overproduction of phenolic compounds following chitosan treatment has been reported in several fruit trees, like papaya (Ali et al., 2012), litchi (Zhang and Quantick, 1997), apricot (Ghasemnezhad and Shiri, 2010), and loquat (Ghasemnezhad et al., 2011). Along with $\mathrm{H}_{2} \mathrm{O}_{2}$, chitosan is also involved in the stimulation of $\mathrm{NO}$ in plant tissues. It was proposed that exogenous application of oligochitosan resulted in $\mathrm{NO}$ generation in chloroplast, nucleus and finally in the whole cell (Zhang et al., 2011). The production of NO after chitosan application interacts with $\mathrm{ABA}$ negative regulator $\mathrm{ABI}$, leading to ABA signaling and massive gene modulation (Zhang et al., 2004). It has been reported that humic substances induced plant growth by apoplastic acidifying via cross activation of plasma membrane $\mathrm{H}^{+}$-ATP-ase and NO production (Zandonadi et al., 2010). Similarly, the promotion of shoot growth by humic substances can occur through both IAA- and NOdependent pathways (Mora et al., 2014). Upon this type of plant morphological change, the interplay of humic substances and NO has been proposed (Figure 1).

\section{REFERENCES}

Ali, A., Mohamed, M. T. M., and Siddiqui, Y. (2012). Control of Anthracnose by chitosan through stimulation of defence-related enzymes in eksotika II papaya (Carica papaya L.) fruit. J. Biol. Life Sci. 3, 114-126. doi: 10.5296/jbls.v3i1.1306

Ashraf, N., Ashraf, M., Hassan, G., Rehman, M. U., Dar, N. A., Khan, I. M., et al. (2013). Effect of foliar application of nutrients and biostimulant on nut quality

\section{CHALLENGES AND OPPORTUNITIES}

The examples presented in this review documented the potential of foliar-based nutrition and biostimulants to enhance fruit tree performance; however, there are insufficient experimental data on how these treatments affect cell metabolism. Within this context, the application of art systems-biology metadata approaches, based on global analysis of transcriptomes, proteomes and metabolomes together with bioinformatic platforms would substantially contribute to reach this goal. Another interesting area that would be investigated is whether, as in root treatments with priming molecules, leaf-applied biostimulants act as priming elicitors at the whole-plant level, thereby systemically sensed by roots. A model explaining the mode of priming action of $\mathrm{H}_{2} \mathrm{O}_{2}$ and $\mathrm{NO}$ against salinity has been recently proposed by Molassiotis et al. (2016): Using citrus seedlings, the authors showed that phloem is the likely path for self-propagated systemic transmission or movement of $\mathrm{H}_{2} \mathrm{O}_{2}$ and $\mathrm{NO}$ signals from root to leaves. Another field where information is lacking is whether and how foliar nutrition and biostimulants could act synergistically, for example, upon the same type of stress or between biotic and abiotic stresses. Analogously, a scientific area for future research is the combination among some of the various biostimulants presented in this review. It is interesting also to note that a large number of studies are focused on young fruit trees. Thus, it is important to monitor and observe the foliar nutrition/biostimulants effects at the level of an orchard ecosystem, specifically in view of the ever-increasing applications of these materials. Upcoming investigations are also expected to characterize the application method and standardization of treatments for cost-effective fruit protection strategies. Furthermore, the application of both biostimulants and chemical priming agents in young fruit trees in nursery or at the planting stage could be anticipated because it would reduce the costs associated with later cultivation treatments in the orchard. Despite these open questions, the technology of foliar nutrition and biostimulants might be combined with all available modern agronomic practices, such as precision agriculture and innovative decision-making systems, to create novel approaches in fruit tree cultivation.

\section{AUTHOR CONTRIBUTIONS}

GT, VZ and AM wrote the paper.

\section{ACKNOWLEDGMENTS}

The authors apologize to colleagues whose work could not be cited due to space constraints.

and leaf nutrient status of pecan nut cv. "Western Schley." Afr. J. Agric. Res. 8, 559-563. doi: 10.5897/AJAR12.1685

Basak, A. (2008). Effect of preharvest treatment with weaweed products, Kelpak $₫$ and Goëmar BM $86^{\circledR}$, on fruit quality in apple. Int. J. Fruit Sci. 8, 1-14. doi: 10.1080/15538360802365251

Brown, P., and Saa, S. (2015). Biostimulants in agriculture. Front. Plant Sci. 6:671. doi: $10.3389 /$ fpls.2015.00671 
Bulgari, R., Cocetta, G., Trivellini, A., Vernieri, P., and Ferrante, A. (2015). Biostimulants and crop responses: a review. Biol. Agric. Hortic. 31, 1-17. doi: 10.1080/01448765.2014.964649

Chouliaras, V., Gerascapoulos, D., and Lionakis, S. (1997). Effects of seaweed extract on fruit growth, weight and maturation of 'Hayward' kiwifruit. Acta Hortic. 444, 485-492. doi: 10.17660/ActaHortic.1997.444.74

Chouliaras, V., Tasioula, M., Chatzissavvidis, C., Therios, I., and Tsabolatidou, E. (2009). The effects of a seaweed extract in addition to nitrogen and boron fertilization on productivity, fruit maturation, leaf nutritional status and oil quality of the olive (Olea europaea L.) cultivar Koroneiki. J. Sci. Food Agric. 89, 984-988. doi: 10.1002/jsfa.3543

Colavita, G. M., Spera, N., Blackhall, V., and Sepulveda, G. M. (2011). Effects of seaweed extract on pear fruit quality and yield. Acta Hortic. 909, 601-607. doi: 10.17660/ActaHortic.2011.909.72

Colla, G., Rouphael, Y., Canaguier, R., Svecova, E., and Cardarelli, M. (2014). Biostimulant action of a plant-derived protein hydrolysate produced through enzymatic hydrolysis. Front. Plant Sci. 5:448 doi: 10.3389/fpls.2014.00448

Conrath, U. (2011). Molecular aspects of defence priming. Trends Plant Sci. 16, 524-531. doi: 10.1016/j.tplants.2011.06.004

Davarpanah, S., Tehranifar, A., Davarynejad, G., Abadía, J., and Khorasani, R. (2016). Effects of foliar applications of zinc and boron nano-fertilizers on pomegranate (Punica granatum cv. Ardestani) fruit yield and quality. Sci. Hortic. 210, 57-64. doi: 10.1016/j.scienta.2016.07.003

Dubravec, K., Dubravec, I., and Manitasevic, J. (1995). The effect of the bioregulators Agrispon ${ }^{\circledR}$ and Ergostim on the vegetative and reproductive growth of apples. J. Sustain. Agric. 5, 73-83. doi: 10.1300/J064v05n01_06

du Jardin, P. (2015). Plant biostimulants: definition, concept, main categories and regulation. Sci. Hortic. 196, 3-14. doi: 10.1016/j.scienta.2015.09.021

El-Boray, M. S., Mostafa, M. F. M., Salem, S. E., and El-Sawwah, O. A. O. (2015). Improving yield and fruit quality of Washington Navel orange using foliar bapplications of some natural biostimulants. J. Plant Prod. Masoura Univ. 6, 1317-1332.

El-Jendoubi, H., Melgar, J. C., Álvarez-Fernández, A., Sanz, M., Abadía, A., and Abadía, J. (2011). Setting good practices to assess the efficiency of iron fertilizers. Plant Physiol. Biochem. 49, 483-488. doi: 10.1016/j.plaphy.2011.02.013

El-Jendoubi, H., Vázquez, S., Calatayud, A., Vavpetič C. P., Vogel-Mikuš, K., Pelicon, P., et al. (2014). The effects of foliar fertilization with iron sulfate in chlorotic leaves are limited to the treated area. a study with peach trees (Prunus persica L. Batsch) grown in the field and sugar beet (Beta vulgaris L.) grown in hydroponics. Front. Plant Sci. 5:2. doi: 10.3389/fpls.2014.00002

Fathy, M. A., Gabr, M. A., and El Shall, S. A. (2010). Effect of humic acid treatments on 'Canino' apricot growth, yield and fruit quality New York. Sci. J. 3, 109-115.

Fatma, K. M. S., Morsey, M. M., and Thanaa, S. M. M. (2015). Influence of spraying yeast extract and humic acid on fruit maturity stage and storability of "Canino" apricot fruits. Int. J. ChemTech. Res. 8, 530-543.

Featonby-Smith, B. C., and van Staden, J. (1987). Effect of seaweed concentrate on yield and seed quality of Arachis hypogaea. S. Afr. J. Bot. 53, 190-193. doi: 10.1016/S0254-6299(16)31429-6

Fernández, V., and Brown, P. H. (2013). From plant surface to plant metabolism: the uncertain fate of foliar applied nutrients. Front. Plant Sci. 4:289. doi: 10.3389/fpls.2013.00289

Fernández, V., and Eichert, T. (2009). Uptake of hydrophilic solutes through plant leaves: current state of knowledge and rerspectives of foliar fertilization. Crit. Rev. Plant Sci. 28, 36-68. doi: 10.1080/07352680902743069

Fernández,V., Sotiropoulos,T., and Brown, P.H. (2013). Foliar Fertilisation: Principles and Practices. Paris: International Fertilizer Industry Association (IFA).

Fernández, V., Guzmán-Delgado, P., Graça, J., Santos, S., and Gil, L. (2016). Cuticle structure in relation to chemical composition: re-assessing the prevailing model. Front. Plant Sci. 7:427. doi: 10.3389/fpls.2016.00427

Fernández-Escobar, R., Benlloch, M., Barranco, D., Due-as, A., and Gaán, J. A. G. (1996). Response of olive trees to foliar application of humic substances extracted from leonardite. Sci. Hortic. 66, 191-200. doi: 10.1016/S0304-4238(96)00914-4

Fornes, F., Sánchez-Perales, M., and Guardiola, J. L. (2002). Effect of a seaweed extract on the productivity of 'de Nules' Clementine mandarin and Navelina orange. Bot. Mar. 45, 486-489. doi: 10.1515/BOT.2002.051
Gao, H., Zhang, Z. K., Chai, H. K., Cheng, N., Yang, Y., Wang, D. N., et al. (2016). Melatonin treatment delays postharvest senescence and regulates reactive oxygen species metabolism in peach fruit. Postharvest Biol. Technol. 118, 103-110. doi: 10.1016/j.postharvbio.2016.03.006

Ghasemnezhad, M., Nezhad, M. A., and Gerailoo, S. (2011). Changes in postharvest quality of loquat (Eriobotrya japonica) fruits influenced by chitosan. Hortic. Environ. Biotech. 52, 40-45. doi: 10.1007/s13580-011-0028-5

Ghasemnezhad, M., and Shiri, M. A. (2010). Effect of chitosan coatings on some quality indices of apricot (Prunus armeniaca L.) during cold storage. Casp. J. Environ. Sci. 8, 25-33.

Gurav, R. G., and Jadhav, J. P. (2013). A novel source of biofertilizer from feather biomass for banana cultivation. Environ. Sci. Pollut. Res. 20, 4532-4539. doi: $10.1007 / \mathrm{s} 11356-012-1405-\mathrm{z}$

Hagagg, L. F., Shahin, M. F. M., Merwad, M. A., Khalil, F. H., and El-Hady, E. S. (2013). Improving fruit quality and quantity of "Aggizi" olive trees by application of humic acid during full bloom and fruit set stages. Middle East J.Agric. Res. 2, 44-50.

Ibrahim, R. Z. (2013). Effect of foliar spray of ascorbic acid, Zn, seaweed extracts (sea) force and biofertilizers (EM-1) on vegetative growth and root growth of olive (Olea europaea L.) transplants cv. HojBlanca. Int. J. Pure Appl. Sci. Technol. 17, 79-89.

Karthikeyan, K., and Shanmugam, M. (2014). Enhanced yield and quality in some banana varieties applied with commercially manufactured biostimulant aquasap from sea plant Kappaphycus alvarezii J. Agric. Sci. Tech. 4, 621-631. doi: 10.17265/2161-6264/2014.08.004

Kerch, G. (2015). Chitosan films and coatings prevent losses of fresh fruit nutritional quality: a review. Trends Food Sci. Technol. 46, 159-166. doi: 10.1016/j.tifs.2015.10.010

Koksal, A., Dumanoglu, H., Gunes, N., and Aktas, M. (1999). The effects of different amino acid chelate foliar fertilizers on yield, fruit quality, shoot growth and $\mathrm{Fe}, \mathrm{Zn}, \mathrm{Cu}, \mathrm{Mn}$ content of leaves in Williams pear cultivar (Pyrus communis L.). Turk. J. Agric. For. 23, 651-658.

Kostopoulou, Z., Therios, I., Roumeliotis, E., Kanellis, A. K., and Molassioltis, A. (2015). Melatonin combined with ascorbic acid provides salt adaptation in Citrus aurantium L. seed. Plant Physiol. Biochem. 86, 155-165. doi: 10.1016/j.plaphy.2014.11.021

Kunicki, E., Grabowska, A., Sękara, A., and Wojciechowska, R. (2010). The effect of cultivar type, time of cultivation, and biostimulant treatment on the yield of spinach (Spinacia oleracea L.). Folia Hortic. 22, 9-13. doi: 10.2478/fhort-2013-0153

Little, H. A., and Spann, T. M. (2010). Commercial extracts of Ascophyllum nodosum increase growth and improve water status of potted citrus rootstocks under deficit irrigation. Hortscience 45.

Mohamed, A. Y., and El-Sehrawy, O. A. M. (2013). Effect of seaweed extract on fruiting of Hindy Bisinnara mango trees. J. Am. Sci. 9, 537-544.

Molassiotis, A., Job, D., Ziogas, V., and Tanou, G. (2016). Citrus plants: a model system for unlocking the secrets of NO and ROS-inspired priming against salinity and drought. Front. Plant Sci. 7:229. doi: 10.3389/fpls.2016. 00229

Molassiotis, A., Tanou, G., Diamantidis, G., Patakas, A., and Therios, I. (2006). Effects of 4-month Fe deficiency exposure on Fe reduction mechanism, photosynthetic gas exchange, chlorophyll fluorescence and antioxidant defense in two peach rootstocks differing in Fe deficiency tolerance. J. Plant Physiol. 163, 176-185. doi: 10.1016/j.jplph.2004.11.016

Mora, V., Bacaicoa, E., Baigorri, R., Zamarreño, A. M., and García-Mina, J. M. (2014). NO and IAA key regulators in the shoot growth promoting action of humic acid in Cucumis sativus L. J. Plant Growth Regul. 33, 430-439. doi: 10.1007/s00344-013-9394-9

Morales-Payan, J. P., and Stall, W. M. (2003). Papaya (Carica papaya) response to foliar treatments with organic complexes of peptides and amino acids. Proc. Fla State Hortic. Soc. 116, 30-32.

Morales-Payan, J. P., and Stall, W. M. (2004). Passion fruit (Passiflora edulis) transplant production is affected by selected biostimulants. Proc. Fla State. Hortic Soc. 117, 224-227.

Nasir, M., Khan, A. S., Basra, S. M. A., and Malik, A. U. (2016). Foliar application of moringa leaf extract, potassium and zinc influence yield and fruit quality of 'Kinnow' mandarin. Sci. Hortic. 210, 227-235. doi: $10.1016 /$ j.scienta.2016.07.032 
Niemann, S., Burghardt, M., Popp, C., and Riederer, M. (2013). Aqueous pathways dominate permeation of solutes across Pisum sativum seed coats and mediate solute transport via diffusion and bulk flow of water. Plant Cell Environ. 36, 1027-1036. doi: 10.1111/pce.12035

Pichyangkura, R., and Chadchawan., S. (2015). Biostimulant activity of chitosan in horticulture. Sci Hortic. 196, 49-65. doi: 10.1016/j.scienta.2015.09.031

Quartieri, M., Lucchi, A., Marangoni, B., Tagliavini, M., and Cavani, L. (2002). Effects of the rate of protein hydrolysis and spray concentration on growth of potted kiwifruit (Actinidia deliciosa) plants. Acta Hortic. 594, 341-347. doi: 10.17660/ActaHortic.2002.594.42

Rios, J. J., Carrasco-Gil, S., Abadía, A., and Abadía, J. (2016). Using Perls staining to trace the iron uptake pathway in leaves of a Prunus rootstock treated with iron foliar fertilizers. Front. Plant Sci. 7:893. doi: 10.3389/fpls.2016.00893

Saa, S., Olivos-Del Rio, A., Castro, S., and Brown, P. H. (2015). Foliar application of microbial and plant based biostimulants increases growth and potassium uptake in almond (Prunus dulcis [Mill.] D. A. Webb). Front. Plant Sci. 6:87. doi: $10.3389 /$ fpls.2015.00087

Schreiber, L. (2005). Polar paths of diffusion across plant cuticles: new evidence for an old hypothesis. Ann. Bot. 95, 1069-1073. doi: 10.1093/aob/mci122

Sekhon, B. S. (2014). Nanotechnology in agri-food production: an overview. Nanotechnol. Sci. Appl. 7, 31-53. doi: 10.2147/NSA.S39406

Singh, N. B., Amist, A., Yadav, K., Singh, D., Pandey, J. K., and Singh, S. C. (2013). Zinc oxide nanoparticles as fertilizer for the germination, growth and metabolism of vegetable crops. J. Nanoeng. Nanomanuf. 3, 353-364. doi: 10.1166/jnan.2013.1156

Spann, T. M., and Little, H. A. (2011). Applications of a commercial extract of the brown seaweed Ascophyllum nodosum increases drought tolerance in container-grown 'Hamlin' sweet orange nursery trees. HortScience 46, 577-582.

Subramanian, K. S., Manikandan, A., Thirunavukkarasu, M., and Sharmila Rahale, C. (2015). "Nano-fertilizers for balanced crop nutrition," in Nanotechnologies in Food and Agriculture, eds M. Rai, C. Ribeiro, L. Mattoso,and N. Duran (Switzerland:Springer), 69-80.

Tanou, G., Filippou, P., Belghazi, M., Job, D., Diamantidis, G., Fotopoulos, V., et al. (2012a). Oxidative and nitrosative-based signaling and associated posttranslational modifications orchestrate the acclimation of citrus plants to salinity stress. Plant J. 72, 585-599. doi: 10.1111/j.1365-313X.2012.05100.x

Tanou, G., Fotopoulos, V., and Molassiotis, A. (2012b). Priming against environmental challenges and proteomics in plants: update and agricultural perspectives. Front. Plant Sci. 3:216. doi: 10.3389/fpls.2012.00216

Tanou, G., Job, C., Rajjou, L., Arc, E., Belghazi, M., Diamantidis, G., et al. (2009). Proteomics reveals the overlapping roles of hydrogen peroxide and nitric oxide in the acclimation of citrus plants to salinity. Plant J. 60, 795-804. doi: 10.1111/j.1365-313X.2009.04000.x

Thippeshappa, G. N., Ravi, C. S., and Ramesha, Y. S. (2014). Influence of soil and foliar application of silicon on vegetative characters, fruit yield and nutrients content of sapota leaf. Res. Crops 15, 626-630. doi: $10.5958 / 2348-7542.2014 .01387 .4$

Vance, C. P. (2001). Symbiotic nitrogen fixation and phosphorus acquisition. Plant nutrition in a world of declining renewable resources. Plant Physiol. 127, 390-397. doi: 10.1104/pp.010331

Viti, R., Bartolini, S., and Vitagliano, C. (1990). Growth regulators on pollen germination in olive. Acta Hortic. 286, 227-230. doi: 10.17660/ActaHortic.1990.286.47
Wang, N., Yang, C., Pan, Z., Liu, Y., and Peng, S. (2015). Boron deficiency in woody plants: various responses and tolerance mechanisms. Front. Plant Sci. 6:916. doi: $10.3389 /$ fpls.2015.00916

Wang, P., Yin, L., Liang, D., Li, C., Ma, F., and Yue, Z. (2012). Delayed senescence of apple leaves by exogenous melatonin treatment: toward regulating the ascorbate-glutathione cycle. J. Pineal Res. 53, 11-20. doi: 10.1111/j.1600-079X.2011.00966.x

Wójcik, P. (2004). Uptake of mineral nutrients from foliar fertilization. J. Fruit Ornam. Plant Res. 12, 201-218.

Wójcik, P., Gubbuk, H., Akgül, H., Gunes, E., Ucgun, K., Koçal, H., et al. (2010). Response of 'Granny Smith' apple trees to foliar titanium sprays under conditions of low soil availiability of iron, manganese, and zinc. J. Plant Nutr. 33, 1914-1925.doi: 10.1080/01904167.2010. 512051

Zandonadi, D. B., Santos, M. P., Dobbss, L. B., Olivares, F. L., Canellas, L. P., Binzel, M. L., et al. (2010). Nitric oxide mediates humic acids-induced root development and plasma membrane $\mathrm{H}^{+}$-ATPase activation. Planta 231, 1025-1036. doi: 10.1007/s00425-010-1106-0

Zhang, D., and Quantick, P. C. (1997). Effects of chitosan coating on enzymatic browning and decay during postharvest storage of litchi (Litchi chinensis Sonn.) fruit. Postharvest Biol. Technol. 12, 195-202. doi: 10.1016/S0925-5214(97)00057-4

Zhang, H., Zhao, X., Yang, J., Yin, H., Wang, W., Lu, H., et al. (2011). Nitric oxide production and its functional link with OIPK in tobacco defense response elicited by chitooligosaccharide. Plant Cell Rep. 30, 1153-1162. doi: 10.1007/s00299-011-1024-z

Zhang, W., Qin, C., Zhao, J., and Wang, X. (2004). Phospholipase D $\alpha 1$ derived phosphatidic acid interacts with $\mathrm{ABI} 1$ phosphatase $2 \mathrm{C}$ and regulates abscisic acid signaling. Proc. Natl. Acad. Sci. U.S.A. 101, 9508-9513. doi: 10.1073/pnas.0402112101

Zhao, X., She, X., Du, Y., and Liang, X. (2007). Induction of antiviral resistance and stimulary effect by oligochitosan in tobacco. Pestic. Biochem. Phys. 87, 78-84. doi: 10.1016/j.pestbp.2006.06.006

Ziogas, V., Tanou, G., Belghazi, M., Filippou, P., Fotopoulos, V. Grigorios, D., et al. (2015). Roles of sodium hydrosulfide and sodium nitroprusside as priming molecules during drought acclimation in citrus plants. Plant Mol. Biol. 89, 433-450. doi: 10.1007/s11103-0150379-x

Zulaikha, R. I. (2013). Effect of foliar spray of ascorbic acid, Zn, seaweed extracts (sea) force and biofertilizers (EM-1) on vegetative growth and root growth of Olive (Olea europaea L.) transplants cv. HojBlanca. Int. J. Pure Appl. Sci. Technol. 17, 79-89.

Conflict of Interest Statement: The authors declare that the research was conducted in the absence of any commercial or financial relationships that could be construed as a potential conflict of interest.

Copyright (c) 2017 Tanou, Ziogas and Molassiotis. This is an open-access article distributed under the terms of the Creative Commons Attribution License (CC BY). The use, distribution or reproduction in other forums is permitted, provided the original author(s) or licensor are credited and that the original publication in this journal is cited, in accordance with accepted academic practice. No use, distribution or reproduction is permitted which does not comply with these terms. 